\title{
CULTURAL DISCOURSE ON XUE SUSU, A COURTESAN IN LATE MING CHINA
}

\section{Daria Berg}

University of Nottingham

E-mail daria.berg@nottingham.ac.uk

This paper investigates perceptions of courtesans, gender and power from various perspectives, using both literary and non-literary sources and reconstructed lost books. Analysis focuses on representations of the celebrated courtesan, poet and painter Xue Susu (fl. I575-before I652) by writers of different backgrounds, gender and class. In late Ming times women participated in elite culture in unprecedented numbers. Courtesans gained prominence in the literati arts, playing a formative role in shaping cultural ideals. Late imperial Chinese discourse embeds the image of the courtesan in the formation of new beauty ideals and social negotiations of gender roles and power. Paradoxes abound, linking the courtesan with notions of chivalry, chastity and loyalism and depicting her in the context of national politics and warfare. The Ming/Qing texts reflect not only current perceptions of women and courtesans, but also the social and cultural aspirations, dreams, anxieties and desires of their authors.

\section{INTRODUCTION}

One autumn day in the I580s the celebrated courtesan Xue Susu 薛素素 (c. I575-before I652) invites her client Censor He 何侍御, a high-ranking scholar-official in the service of the Wanli 萬曆 emperor (r. I573-I620), to drink with her in the Qinhuai 秦淮 pleasure quarters, Nanjing’s 南京 legendary entertainment district. ${ }^{I}$ Yet she not only entertains her guest: she also writes about the event, committing it to paper in the form of a poem and to public memory by virtue of publishing her writings.

Through acts of writing and publishing the courtesan invites us - the modern critic and reader, the historian who makes the dead speak - to eavesdrop on the event. By transmitting

\footnotetext{
I am most grateful to Professors Glen Dudbridge, Allan Barr, Grace Fong and Joseph Poon for commenting on various versions of the manuscript; Professor Allan Barr for obtaining rare materials from China; Dr Carolyn Ford, Mark Strange and Ka Chai Tam for help with locating bibliographical items; and the anonymous reviewers. Research for this article was sponsored by a Leverhulme Trust fellowship. Earlier versions were presented at the conferences "Narrating and Imaging the Nation: Gender, Sexuality and the Nation", SOAS, London, June 2002; the Annual Meeting of the Association for Asian Studies, New York, NY, March 2003; and "Elites in Asian History: Social Network and Cultural Representation”, University of Tokyo, February 2006; it has been a privilege to share work in progress with the expert audiences.
}

I Alias Xue Wu 薛五, Runqing 潤卿, Runniang 潤娘, Suqing 素卿, Sujun 素君, Wulang 五郎, Qiaoqiao 巧巧 and Xuesu 雪素. 
Xue Susu's writings across time and space, her anthologists enable us to revisit the Qinhuai pleasure quarters through her eyes. This essay sets out to analyse the perceptions of the courtesan and her world, aiming to retrace the network of social negotiations and exchanges in the discourse on Xue Susu and to contribute to a deeper understanding of women's self-fashioning and cultural representations in late imperial China.

Xue Susu counts among the most accomplished women artists and entertainers in China during the late Ming 明 era (I368-I644), yet her life and works remain underresearched - in contrast to other Chinese courtesans, most notably Liu Rushi 柳如是 (I6I8-I664). ${ }^{2}$ In late imperial times Xue Susu ranked among the "Eight Great Courtesans of the Ming Dynasty". 3 Today her paintings, calligraphy and seals grace museums in China, Japan and the US, ${ }^{4}$ yet apart from Yu-ho Tseng's I955 article few scholarly works discuss her in detail. ${ }^{5}$ Only a handful of Xue Susu's poems have been translated into Western languages so far. ${ }^{6}$ A free spirit full of complexities, she merits a closer look to see what her story can tell us about women, life and culture in late imperial China.

This study uses an interdisciplinary approach to revisit the discourse about late imperial Chinese courtesans and to examine the cultural discourse on Xue Susu, using both literary and non-literary texts as historical source material. It focuses on the literary works by Xue Susu alongside writings about her by male and female authors, aiming to shed light on her acts of self-fashioning, social aspirations and cultural representations. The discourse about Xue Susu is linked to that about the Qinhuai entertainment district in Nanjing. I have discussed the history of the Qinhuai and the role of the Chinese courtesan elsewhere.7 Here I place Xue Susu's writings and the discourse about her into their literary, social and historical contexts to see what they can tell us about perceptions of life, women and culture in late Ming times.

This approach takes inspiration from Emmanuel Le Roy Ladurie's concept of the historian as a messenger of souls whose task it is to make the dead speak, and also from the New Historicist concept of the network of social negotiations and exchanges that shows how a text circulates inseparably from its literary and non-literary contexts. ${ }^{8}$ Modern literary critics Stephen Greenblatt and Catherine Gallagher applied similar approaches to the study of Shakespeare, Renaissance self-fashioning and women's literature in England. 9 The sinologist Glen Dudbridge has pioneered a related style of reading in his study of

2 On Liu Rushi, see, e.g., Chen Yinke I980; Chang I991.

3 Tseng I955, p. 205.

4 The Palace Museum Beijing, Nanjing Museum, Shanghai Museum, Jilin Province Museum, Yokohama Museum, Honolulu Academy of Arts, The Asian Art Museum of San Francisco.

5 For brief treatises, see Chen Shan 2007; Liu Suping 2007; Weidner et al. I988, pp. 82-88; Barr I997, pp. I2 I-22; Cass I999, pp. 25ff; Wetzel 2002.

6 Four poems are translated into English in Chang and Saussy I999 [hereafter: WWTC], pp. 227-29.

7 Cf. Berg 2007a. On courtesan culture, see Ōki 2002a; Zeitlin 2006; Widmer and Chang I997.

8 Le Roy Ladurie I980.

9 Greenblatt I988, p. I. 
Tang 唐 dynasty (6r8-907) Chinese narratives. ${ }^{\text {Io }}$ I have discussed the implications of using such an approach for a poetics of Chinese culture elsewhere. ${ }^{\text {II }}$

The Chinese term ji 妓 refers to both the common lowly prostitute and the high-class courtesan, deriving from a combination of the graphs for woman 女 and entertainer 伎 ${ }^{12}$ Modern scholars have translated it as geisha 芸者, ${ }^{13}$ a suitable term insofar as it means "artist", but this term remains peculiar to the Japanese context with its strict training process and hierarchy. The Chinese system lacked such clear-cut distinctions. High-class courtesans (mingji 名妓) differed from common prostitutes by virtue of their fame and artistic talent as poets, painters and performers who were not primarily paid for sexual services. Their history dates back to the institution of female entertainers (nӥ yue 女樂) at the Zhou 周 dynasty court (eleventh century to 256 BC). In the late Ming era courtesans shared in literati culture, formed intellectual companionships with elite men and featured prominently in their writings. Despite their low legal status the courtesan's fame rested on excellence in literature and the arts, mirroring her male literati clients whose elite status and power derived from their command of the realm of letters, as evidenced by success in the civil service examinations.

The courtesan thrived within a complex network of social negotiations and exchanges that involved not only the leading members of China's literary, political, military and financial elites - the literati or Confucian gentlemen, scholar-officials, military commanders, wealthy merchants - but also the gui xiu 閨秀, ruling class "gentlewomen" and other courtesans. The concept of exchange played an important role in Ming/Qing 清 (I644-I9II) discourse, and poetry was one of its currencies. Xue Susu acquired fame as a poet, painter and performer in literati circles. Ruling-class men and women praised her beauty, artistic achievements and skills as a horsewoman and archer. She contributed to the formation of new beauty ideals in late Ming China, as the literati began to celebrate women who combined talent, beauty and virtue ${ }^{\mathrm{I} 4}$ - an ideal that appears to link the attributes and accomplishments celebrated in courtesans with the moral values usually associated with gentlewomen and the chastity cult. Paradoxes abound, linking the courtesan with notions of chivalry, chastity and loyalism while depicting her in the context of national politics and warfare. Analysis of the Ming/Qing discourse on Xue Susu provides not only insights into early modern Chinese perceptions of women but also the social and cultural aspirations, dreams, anxieties and desires of those who wrote about them.

The endeavour to analyse Xue Susu's poetic exchanges and to retrace the negotiations involved in the social network around her relies on the reconstruction of lost sources, as well as rethinking the approach to literary and historical source materials. ${ }^{15}$ Xue Susu published two volumes of poetry, yet only one survives, in part. The following aims to

Io Dudbridge I995.

II Berg 2003 .

I 2 Cf. Zeitlin 2006, pp. 75-76.

I 3 Cf. Cass I999, p. 28.

I4 Cf. Ko I994, pp. I43-76.

I5 On reconstructing China's lost books, see Dudbridge 2000. 
reconstruct the discourse on the courtesans' world from Xue Susu's lost volume of poetry and place the recovered discourse into its cultural and historical contexts.

The essay divides into five main parts: first, an outline of Xue Susu's life; second, a reconstruction of her literary works; third, an analysis of Xue Susu's poetic voice, concluding with a consideration of her lyrical masks and the implied readership; fourth, her representations by literary men; and finally, the discourse about her by other writing women.

\section{BIOGRAPHICAL RECONSTRUCTION}

The sources are divided about the details of Xue Susu's birth, career and death. She was born either in Suzhou 蘇州 or Jiaxing 嘉興. ${ }^{6}$ Xue Susu first emerged in the public eye sometime prior to I588 when the leading painter and aesthete Dong Qichang 董其昌 (I555-I636) admired her painting of bodhisattva Guanyin 觀音, composed a colophon and copied out the Xin jing 心經 (Heart Sutra) to accompany it. ${ }^{17}$ She must have been at least in her teens by then, suggesting a date of birth sometime between I570 and I575.

Xue Susu rose to prominence as a Qinhuai courtesan during the I580s. Perhaps Xue Susu did not stay there long enough to make it into Yu Huai's 余懷 (I6I6-I696) Ban qiao za ji 板橋雜記 (Miscellaneous reminiscences of [the pleasure quarters by] plank bridge, I697). ${ }^{18}$ Perhaps there were simply too many celebrated courtesans, or perhaps the omission is due to the fact that Xue Susu's career preceded Yu Huai by over half a century. Yu Huai stated his regret about being born too late to have made the acquaintance of the most famous Wanli era courtesans, such as Ma Xianglan 馬湘蘭 (I548-I604). ${ }^{\text {I9 }} \mathrm{Ma}$ Xianglan knew Xue Susu: the two courtesans worked together on a joint painting of orchids “Lan hua tu” 蘭花圖 (“Painting of Orchids”, I60I). ${ }^{20}$ This suggests that Xue Susu had connections with the Qinhuai at least until I60I. ${ }^{21}$

Xue Susu seems to have clinched her celebrity status in literati circles later on during her stay in Beijing in the I590s, where she hosted poetry parties and literary soirées for literati, officials and military officers. ${ }^{22}$ She would entertain her patrons with her poetry and play a jade lute at banquets. ${ }^{23}$ Her martial spirit earned her a reputation as an archer, horsewoman and knight-errant, and she would display her Amazonian skills on horseback in public. She even became involved in political campaigns. One late Ming connoisseur, National University student Pan Zhiheng 潘之恆 (I556-I622) from Huizhou 徽州 confirmed Xue Susu's reputation in 1605 :

Chen Yinke I980, pp. 47I-72.

Zhu Yizun I705.98.5a. On Dong Qichang, see Hummel I943-I944 [hereafter: ECCP], p. 787.

On Yu Huai (zi Wuhuai 無懷), see ECCP, p. 942; Ōki 2006.

See Yu Huai I697, B.5. On Ma Xianglan (Shouzhen 馬守真), see Weidner et al. I988, pp. 72-8I; WWTC, pp. 230-3I; Idema and Grant 2004, pp. 364-68.

Artistic collaboration was not uncommon for courtesans, as Ōki Yasushi has shown in his study of Gu Mei and Liu Rushi; Ōki 2002b, pp. 7-I8.

Cf. Gugong bowuguan 2007.

Wang Tonggui I603, 34.I2a.

Li Yingzheng I644-I9II, I.Igb. 
Among the courtesans in the capital Wang Xuexiao 王雪簫 ranks top in literary talent and Cui Ziyu 崔子玉 ranks top in martial arts performance, but Xue Susu combines excellence in both. ${ }^{24}$

Despite Xue Susu's public prominence, she almost disappeared from sight when her career as a courtesan ended. Sometime after I605 she became the concubine of scholardramatist Shen Defu 沈德符 (I578-I642) from Jiaxing. ${ }^{25}$ Xue Susu's marital history may explain her relative invisibility from the early seventeenth century until her death: Li Yingzheng 李應徵 expressed regret that since Xue Susu's wedding to Shen Defu she was being kept under wraps and out of circulation. ${ }^{26}$

A biographical sketch of Xue Susu appeared in an appendix to Qian Qianyi’s 錢謙益 (I608-I664) anthology Lie chao shi ji 列朝詩集 (Collection of Poetry from Successive Reigns) in I652. Qian Qianyi's work informs us that Xue Susu was married several times but none of the unions lasted. ${ }^{27}$ It is conceivable that she outlived her husbands, as courtesans often married older men, although at least her first marriage to the slightly younger Shen Defu must have ended much earlier. Another possibility is that her husbands terminated the marriage as men often passed courtesan concubines on to another. A courtesan would sometimes herself decide to end the relationship. ${ }^{28}$ Literati writings claim that Xue Susu terminated at least one of her unions and that other courtesans managed to escape from unsatisfactory marriages. ${ }^{29}$ It is not clear exactly how her marriages ended, although contemporary observer Hu Yinglin 胡應麟 (I55I-I602) portrayed Xue Susu as capable of loyalty and commitment. ${ }^{\circ}$

Xue Susu's other husbands included the scholar-official, painter and art critic Li Rihua 李日華 (I565-I635), ${ }^{3 \mathrm{I}}$ and military officer Li the Subduer of Barbarians (Li Zhengman) 李 征蠻, possibly referring to either Li Chengliang 李成梁 (I526-I6I8),32 a general around fifty years her senior who blocked repeated invasions of the Mongols and Manchus in the north and west, or - more likely perhaps - Li Hualong 李化龍 (I554-I6I2, jinshi I574), a poet and military strategist who successfully suppressed a rebellion by the Miao 苗 ethnic minority in Sichuan 四川 and Guizhou 貴州 and conquered its local chieftainship in I600.33 In old age she became the concubine of a wealthy merchant from Suzhou. 34

Cf. Gōyama 2006, p. 552.

On Shen Defu, see Goodrich and Fang I976 [hereafter: $D M B$ ], I I90-9I.

Li Yingzheng I644-I9I I, I.I9a. I am grateful to Allan Barr for his comments on courtesans' marital histories.

Qian Qianyi I957, p. 770.

Cf. Yu Huai 1697.

For Song Maocheng's account of Xue Susu's affair (probably not a marriage) with Yuan Baode, see below.

Hu Yinglin I646, p. 5a. On Hu Yinglin, see $D M B, 645-47$.

On Li Rihua, see $D M B$, pp. 826-30.

On Li Chengliang, see ECCP, pp. 450-52; Barr I997, p. I 22.

On Li Hualong, see $D M B$, pp. 822-26. Here I am indebted to Allan Barr.

Qian Qianyi I957, 770. Qian Qianyi’s biography of Xue Susu seems to imply a sense of regret and sympathy with Xue Susu's fate in her final years when old age appears to have restricted her choices. If Qian Qianyi's wife, the 
Xue Susu's paintings can be dated from I598 to I637, although other undated works also exist. 35 It is possible that she lived into the I640s or even the early I650s, for she participated in a circle of women artists in Hangzhou 杭州 around that time - including the gentlewoman Huang Yuanjie 黃媛介 (c. I620-before I669) and the courtesan Li Yin 李因 (I6I6-I685) who had married into the elite: as neighbours on the shores of the West Lake they exchanged calligraphy and paintings to entertain each other. ${ }^{6}{ }^{6}$ Qian Qianyi's anthology mentions Xue Susu's death. ${ }^{37}$ The publication date of this anthology, 1652, hence appears as the late limit for Xue Susu's lifetime.

\section{RECONSTRUCTING XUE SUSU'S LOST BOOK}

Xue Susu's writings appeared in two volumes: Nan you cao 南游草 (Jottings from a Journey to the South), which is no longer extant, and Hua suo shi 花瑣事 (Trifles about Flowers), a slim edited anthology of prose pieces on the motif of flowers. ${ }^{38}$ It is not clear whether Hua suo shi originally contained more than the eighteen short anecdotes preserved in Qing dynasty collectanea Shui bian lin xia 水邊林下 (Riverside under the Trees) by Hunan Manshi 湖南漫士. The volume consists of Xue Susu's adaptations or retellings of short titled anecdotes from previous dynasties.

The lost volume Nan you cao seems to have contained Xue Susu's original poetry, including her poems on courtesan life. According to a late Ming anthology, Nan you cao included a preface by Wang Zhideng 王稚登 (I535-I6I2), a poet, dramatist and editor of a local gazetteer from Suzhou who became the patron and lover of Ma Xianglan.39 The preface, or part of it, is reproduced in one early Qing anthology.40 The preface implies that Wang Zhideng may have participated in the production process of Xue Susu's writings. Others may also have been involved in compiling or publishing Xue Susu's works but their identities remain obscure. In late imperial China a writing woman's lover or husband would normally support or sponsor her publications. ${ }^{4 \mathrm{I}}$ These mentors would often contribute the prefaces that graced the women's works. It is therefore possible that Xue Susu's lovers or husbands also supported her publications.

famous ex-courtesan Liu Rushi, indeed contributed to the biographies of women writers in his anthology, then perhaps this comment on Xue Susu conveys the perception of a female voice from seventeenth-century China (see also discussion below). In I652, when Qian Qianyi’s anthology was published, Liu Rushi had already married into the elite, but her suicide after Qian Qianyi's death in I664 suggests that she always remained aware of the precariousness and volatility of a courtesan's status and position.

For a list of her paintings, see He Junhong 2004, p. 38.

Yun Zhu I831-I836, fulu.I6b.

Qian Qianyi I957, p. 770.

38 Xue Susu r644-I9II, pp. 658-59.

39 Zhong Xing I6I2-I644, 3I.r2a. On Wang Zhideng ( $z$ i Bogu 伯穀, Baigu 百穀), see DMB, pp. I36I-63. The famous “Rouge Inkstone” Zhi yan 脂硯 of the Hong lou meng Zhi yan zhai 脂硯齋 commentary is associated with Xue Susu and Wang Zhideng, who gave it to Xue Susu as a gift and inscribed it with a quatrain for her. It later came into Zhi yan zhai's hands. He based his pseudonym on it out of admiration for Xue Susu; cf. Zhou Ruchang I973; Chen Shan 2007, p. 92.

$\mathrm{Xu}$ Shumin and Qian Yue I69o, 6.6b-7a. 
Figure r. List of late Ming/early Qing anthologies containing Xue Susu's poems

\begin{tabular}{|c|c|c|c|c|}
\hline Date Publ. & Title of Anthology & Editor/s & $\begin{array}{l}\text { Gender of } \\
\text { Editor/s }\end{array}$ & $\begin{array}{l}\text { Poems by Xue } \\
\text { Susu Selected }\end{array}$ \\
\hline I6I 6 & $\begin{array}{l}\text { Qing lou yun yu } \\
\text { 青樓韻語 (Stylish } \\
\text { words from the } \\
\text { pleasure quarters) }\end{array}$ & $\begin{array}{l}\text { Zhang Meng- } \\
\text { zheng } \\
\text { 張夢徵 }\end{array}$ & M & $\begin{array}{l}\text { 2I (many on } \\
\text { Qinhuai life) }\end{array}$ \\
\hline I620 & $\begin{array}{l}\text { Ming yuan hui shi } \\
\text { 明媛彙詩 } \\
\text { (Collection of poetry } \\
\text { by famous ladies) }\end{array}$ & $\begin{array}{l}\text { Zheng } \\
\text { Wenang } \\
\text { 鄭文昂 }\end{array}$ & M & I \\
\hline c. 1626 & $\begin{array}{l}\text { Ming yuan shi gui } \\
\text { 明媛詩歸 (Poetic } \\
\text { retrospective of } \\
\text { famous ladies) }\end{array}$ & $\begin{array}{l}\text { Zhong Xing 鍾 } \\
\text { 惺 (I574- } \\
\text { I624) }\end{array}$ & M & $\begin{array}{l}\text { 4, Nan you cao } \\
\text { cited as source }\end{array}$ \\
\hline I652 & $\begin{array}{l}\text { “Run ji” 閏集 } \\
\text { (“Intercalary } \\
\text { section”), Lie chao } \\
\text { shi ji 列朝詩集 } \\
\text { (Collection of poetry } \\
\text { from successive } \\
\text { reigns) }\end{array}$ & $\begin{array}{l}\text { Qian Qianyi } \\
\text { 錢謙益. with } \\
\text { Liu Rushi } \\
\text { 柳如是 }\end{array}$ & $\mathrm{M}, \mathrm{F}$ & 3 \\
\hline $\begin{array}{l}\text { preface } \\
\text { I652 }\end{array}$ & $\begin{array}{l}\text { Gui xiu ji 闺秀集 } \\
\text { (Gentlewomen's } \\
\text { Anthology) }\end{array}$ & $\begin{array}{l}\text { Ji Xian } \\
\text { (I6I4-I683) } \\
\text { 季嫺 }\end{array}$ & $\mathrm{F}$ & I \\
\hline $\begin{array}{l}\text { preface } \\
\text { I658 }\end{array}$ & $\begin{array}{l}\text { Ran zhi ji 然脂集, } \\
\text { [unpublished } \\
\text { incomplete } \\
\text { manuscript in } \\
\text { Shanghai Library] }\end{array}$ & $\begin{array}{l}\text { Wang shilu } \\
\text { 王士祿 (I626- } \\
\text { 73, js I652) }\end{array}$ & M & $\begin{array}{l}2 \text { (the original } \\
\text { complete work } \\
\text { may have } \\
\text { contained more } \\
\text { poems by Xue } \\
\text { Susu) }\end{array}$ \\
\hline I667 & $\begin{array}{l}\text { Ming yuan shi wei } \\
\text { 明媛詩緯 (The } \\
\text { famous ladies' } \\
\text { Apocryphal Book of } \\
\text { Odes) }\end{array}$ & $\begin{array}{l}\text { Wang } \\
\text { Duanshu 王端 } \\
\text { 淑 (I62I- } \\
\text { c. I706) }\end{array}$ & $\mathrm{F}$ & $\begin{array}{l}\text { 4, Nan you cao } \\
\text { cited }\end{array}$ \\
\hline I690 & $\begin{array}{l}\text { Zhong xiang ci 眾香 } \\
\text { 詞 (Song-lyrics of } \\
\text { many perfumes) }\end{array}$ & $\begin{array}{l}\text { Xu Shumin 徐 } \\
\text { 樹敏 (js I 703), } \\
\text { Qian Yue 錢岳 }\end{array}$ & $\mathrm{M}, \mathrm{M}$ & $\begin{array}{l}\text { 7, Nan you cao } \\
\text { cited }\end{array}$ \\
\hline I705 & $\begin{array}{l}\text { Ming shi zong 明詩 } \\
\text { 綜 (Collected Ming } \\
\text { poetry) }\end{array}$ & $\begin{array}{l}\text { Zhu Yizun 朱 } \\
\text { 䕨尊 (I629- } \\
\text { I709) }\end{array}$ & M & $\begin{array}{l}\text { 4, Nan you cao } \\
\text { cited }\end{array}$ \\
\hline I83I & $\begin{array}{l}\text { Guo chao gui xiu } \\
\text { zheng shi ji 國朝閏 } \\
\text { 秀正始集 (Correct } \\
\text { beginnings: } \\
\text { Gentlewomen's } \\
\text { poetry of our august } \\
\text { dynasty) }\end{array}$ & $\begin{array}{l}\text { Yun Zhu 惲珠 } \\
\text { (I77I-I833) }\end{array}$ & F & I \\
\hline
\end{tabular}

Fragments from Xue Susu's lost volume have to be culled from surviving Ming/Qing anthologies (see Figure I). ${ }^{42}$ Wang Zhideng's preface suggests that Nan you cao must

42 Later anthologies also contain Xue Susu's works, but are not included here as they usually quote from the early anthologies cited above: for example, a collection Xue Susu shi 薛素素詩 Poems by Xue Susu comprising twenty-nine poems was later published from entries in Lie chao shi ji and Ran zhi ji; cf. LFZ, p. 203. 
have been at least compiled, if not published, before his death in I6I2. Zhong Xing's anthology mentioned Nan you cao in I626, making this the late limit for its publication. The variety of anthologies citing Nan you cao suggests that this volume was published and widely circulated in seventeenth-century Jiangnan. New developments in print technology and book distribution led to a publishing boom and mass printing in the late Ming era. ${ }^{43}$ The publishing industry responded to the new craze for works by women and about women, ${ }^{44}$ alongside textbooks for examination candidates, entertainment literature, guidebooks on style, erotic handbooks, literature about emotions, and literary anthologies. Xue Susu's volumes belonged to the new commodities that were being traded among an expanding and increasingly literate urban population.

The history of anthologizing Xue Susu's poems shows that neither Ming nor Qing editors showed much interest in Hua suo shi. The two late Ming male editors Zhang Mengzheng 張夢徵 and Zhong Xing 鍾惺 (I574-I624) - among the first to anthologize Xue Susu's poems in I6I6 and I626 respectively - were interested in her poems about the Qinhuai. The early Qing editors - both male and female - tended to select Xue Susu's poems on lovesickness, loneliness or the appreciation of wine, flowers and nature. Qing editors also picked poems about trips to holy mountains.

The late Ming editors, then, focused on poems about courtesan culture while early Qing editors chose instead poems on emotions, travels and religious topics. It is not clear whether all poems stem from Nan you cao although this is the only source cited. It is also conceivable that the early Qing editors included later poems written after the appearance of the late Ming anthologies. The selection of materials for an anthology ultimately reveals the editor's agenda and historical circumstances. Editorial choices also suggest that the fragments of Xue Susu's writings transmitted in anthologies only tell part of the story.

\section{RECOVERING THE COURTESAN'S POETIC VOICE}

In the following I identify and analyse three representative aspects of Xue Susu's poetic persona in the reconstructed discourse from her lost book of poetry: the companion, lovesick maiden and hermit.

\section{The Companion}

Around one-third of Xue Susu's extant poems celebrate courtesan life and immortalize the names of her clients. 45 Let us return to Xue Susu's portrayal of an intimate moment with Censor He in the Qinhuai pleasure quarters:

\section{Lines Composed while Feasting Censor He on a Day in Autumn}

Here in the Mochou Country of [the Nanjing] Stone Fortification [in the entertainment quarter of Qinhuai], 
I blush that someone like little me has the leading place.

The river glitters, the water's clear, and seagulls swim in pairs;

The sky looks hollow, the clouds serene, and wild geese fly in rows.

Embroidered robe takes a half-share of the lotus colour;

Green wine shares equally the lotus fragrance. ${ }^{46}$

If our temperaments were not mutually compatible,

Would I dare feed Master He with soup and pancakes? ${ }^{47}$

\section{秋日邀何侍御飲得行字}

石頭城裏莫愁鄉,

深媿儂家得擅場。

江潤水晴鷗對浴,

天空雲靜鳰成行。

繡衣半借芙蓉色,

綠酒平分鼠菡香。

不是與君交意氣,

敢將湯餅啖何郎。

The body of the poem consists of four couplets written on the Tang dynasty model of heptasyllabic regulated verse (qi yan lü shi 七言律诗). The opening sequence of place-names sets the stage for the narrative event in the Qinhuai: “Shi tou cheng” 石頭城 refers to an ancient name for the archaic Chu 楚 fortification built where the Qinhuai River flowed into the Yangzi, now part of a park in Nanjing. “Mochou xiang” 莫愁鄉 was one of many places named after the female entertainer and singer Mochou 莫愁 of ancient $\mathrm{Chu}$, who was linked to the Chu capital Yingdu 趴都 (later Jiangling 江陵), another name of which was “Shi cheng” 石城 (Stone Fortification). “Stone Fortification" thus refers both to the Mochou Country at Jiangling and to the mouth of the Qinhuai in Nanjing, setting the stage for the courtesan's feast.

An educated late Ming reader of Xue Susu's poem would recognize the opening line as an allusion to a Tang dynasty poem by Zheng Gu 鄭谷 (c. 848-9I I, jinshi 887) that also opens with a line containing both place-names. ${ }^{48}$ These allusions reveal the courtesan's high level of literacy. Line two gives an air of arch understatement when the narrator the courtesan's poetic persona - refers to herself in the dialect form nong jia 儂家.

The parallelism in the couplet of lines three and four depicts matches in nature and mates from the animal kingdom as metaphors for the human world, with the hint of autumnal migration, thus establishing an imagery of bonding. The following couplet in lines five and six insists on a discourse of equal sharing, with references to the lotus flower (he hua 荷花), homophonous with the guest's surname He 何. These images indirectly suggest a matching of equals, hostess and guest.

46 For dao han, read han dao 萏菡 in Zhong Xing I62 I-I644, 3I.I2b.

47 Zhang Mengzheng I6I6, I.78-79.

48 “Shi cheng” 石城; Quan Tang shi I985 [hereafter: QTS], 676.7742. 
The last couplet in lines seven and eight takes up the suggestion of mutual compatibility of temperament, culminating in the conclusion of the poem that spells out its central theme. These final lines, in which the narrator affirms her rightful status as a hostess equal to this guest, make it clear why she needed to establish her high position in the opening lines. The denouement of the poem, depicting the courtesan feeding her guest with soup and pancakes, can be read as another arch understatement, humble fare deliberately antithetical to the elaborate entertainment of a formal feast. The narrator evokes a cosy intimacy here, in keeping with the spirit of the poem, although the reality may have been much more expensive.

The density of the poem reveals the intricacy, cleverness and subtlety of the courtesan's art, engaging in a dialogue with literati writings. The narrative voice reveals a set of literary, cultural and social negotiations that establish the courtesan as a match for her client. The courtesans' versatility in the arts endows her with the aura of gentility, enhancing her perceived value and marketability in ruling-class circles. ${ }^{49}$ This poem is representative of Xue Susu's other Qinhuai poems that celebrate her relationships in the entertainment district.50 These poems interweave Qinhuai sights and sounds with names of guests and allusions to classical literary models. They culminate in a declaration of emotions exchanged between courtesan and client while insisting on their compatibility of temperament and shared interests. Yet Xue Susu's oeuvre also depicts the darker side of courtesan life.

\section{The Lovesick Maiden}

Consider Xue Susu's expression of lovesickness and loneliness in a heptasyllabic quatrain (jue ju 絕句) composed sometime before I603: ${ }^{5}$

\section{Poem on Longing for Someone}

This lovely night I think of you, wondering whether you will return; $5^{2}$ The lonely lamp shines on me, casting a faint shadow. I clutch one lone pillow, there is nobody to talk to; 53 Moonlight floods the deserted courtyard, tears soak my dress. ${ }^{54}$

$$
\begin{aligned}
& \text { 懷人詩 } \\
& \text { 良夜思君歸不歸, } \\
& \text { 孤燈照客影微微。 } \\
& \text { 撨來獨枕誰相問, } \\
& \text { 明月空庭淚濕衣。 }
\end{aligned}
$$

5 I I infer the date from Wang Tonggui I603, 34.I2a quoting the poem.

52 Liang ye also implies "in the depth of night", but the narrative voice here implies the waste of a potentially lovely night. 
The title of the poem alludes to the locus classicus of the female poetic voice expressing longing for her lover in the Shi jing 詩經 (Book of Odes). 55 These themes appear as common motifs in courtesan poetry. ${ }^{56}$ "Huai ren" 懷人 ("Longing for Someone") also features as the title of two poems by late Ming courtesan Yu Sulan 羽素蘭 alias Weng Ru'an 翁孺安 from Changshu 常熟,57 and four poems by other contemporary women poets, including an anonymous Nanjing courtesan. ${ }^{8}$

The temporal location of the poem is framed by intimations of longing and abandonment that set the mood of the poem, linking the diurnal rhythm of life with emotions, transforming a lovely night into one spoilt by the lover's absence. The motif of the lonely lamp transfers the reader into the scene of a sleepless night in Bo Juyi's 白居易 (772-846) ballad “Chang hen ge” 長恨歌 (“Song of Everlasting Sorrow”), watching the emperor longing for his dead lover, favorite concubine Yang Guifei 楊貴妃.59

Li Bai’s 李白 (70I-762) “Jing ye si” 靜夜思 (“Quiet Night Thoughts”) famously showed that moonlight breeds longing, nostalgia and melancholy. ${ }^{60}$ Similar poetic voices already stem from pre-Tang courtesans' poetry. ${ }^{61}$ Many yue fu 樂府 (music bureau) poems link moonlight with the deserted courtyard, the question regarding a loved one's return, and a dress soaked with tears. ${ }^{62}$ Xue Susu here in particular borrows images and topics from poem No. I9 of “Gu shi shi jiu shou” 古詩十九首 (“Nineteen Old Poems”) from the first or second century AD. ${ }^{63}$ This poetic model presents two points of view: the lonely woman's longing for her lover, and the male traveller's view of life as a journey. ${ }^{64}$ Xue Susu's poem amalgamates the male and female voices, projecting by implication the courtesan's androgyny: the woman as a traveller ( $k e$ 客) lamenting her loneliness on her journey through life in literati style.

Tang poet Dai Shulun 戴叔倫 (732-789) described the traveller's loneliness at an inn at night, far away from his loved ones. ${ }^{65}$ Scholar-statesman Quan Deyu 權德㙉 (759-8I8) described feelings of longing linked with the night, a deserted courtyard and moonlight. ${ }^{66}$ Song dynasty scholar Su Shi 蘇軾 (IO37-IIOI) imagined his deserted courtyard peopled by the moon, the poet's persona and his shadow. ${ }^{67}$ Xue Susu's shadow by contrast fails to provide good company and fades into insignificance, like her poet's persona.

\footnotetext{
55 “Cha wo huai ren, zhi bi zhou xing” 嗟我懷人, 置彼周行, Mao shi zheng yi, IB.9c.

56 Cf. Ōki 2002a, 249.

57 Zhong Xing I62 I-44, 28.8a, 28.9a.

58 Wang Duanshu I667, 22.8a, 23.I2b, 25.6b, 25.17a-b.

59 QTS, 435.4820.

60 QTS, I65.I709.

6I For example, Lu Qinli I983, pp. I04I-43; Idema and Grant 2004, p. I74.

62 Yue fu shi ji I7.2I 7, 42.486, 68.740, 79.835.

63 Gu shi shi jiu shou ji shi I955, 2.45-46.

64 Cf. Nienhauser I986, p. 490.

65 “Chu ye su shi tou yi” 除夜宿石頭驛; QTS, 273.3073.

66 “Chou pei duan gong ba yue shi wu ri ye dui yue jian huai” 酬裴端公八月十五日夜對月見懷; QTS, 325.3647.

67 “Ci yun mao pang fa cao gan yu shi” 次韵毛浐法曹感雨诗; Su Shi 200I, 4: 31.I564-66.
} 
Tang poet Liu Changqing 劉長卿 (c. 7IO-c. 789) soaked his deserted courtyard with rain, ${ }^{68}$ but Xue Susu fills hers with the narrator's tears. The last line culminates in an expression of emotions (qing 情) that anchor Xue Susu's poem in its late Ming context. The literati discourse on emotions grew into a cult when Tang Xianzu 湯顯祖 (I550I6I6) published his drama $M u$ dan ting 牡丹亭 (The Peony Pavilion) in I 589. ${ }^{69}$

Ma Xianglan's verses similarly dramatize the abandoned woman's tears. ${ }^{70}$ The courtesans often described poetry as an outlet for frustration or anger. The Qinhuai courtesan Zhu Wuxia 朱無瑕 (fl. I569), who lived in Xue Susu's neighbourhood at Peach Leaf Ford, wrote the poem “Ba jiao yu” 芭蕉雨 (“Rain on the Banana Leaves”) about the painful process of completing new poems that express feelings of separation and solitude. ${ }^{7 \mathrm{I}}$ Another Wanli era Qinhuai courtesan, Zheng Ruying 鄭如英, described the aftermath of a parting at the Qinhuai river, comparing the flow of its waters to emotions of lovesickness and longing. ${ }^{72}$ The threat of loss and separation must have loomed over most relationships between courtesans and clients. ${ }^{73}$ Ma Xianglan, for example, sought to become Wang Zhideng's concubine but failed in her quest. ${ }^{74}$ She poured out her heart in her poetry. ${ }^{75}$

The theme of the poetic lament about lovesickness in Xue Susu's works thus follows courtesan poetic convention. It delivers the topoi that her literati readership would expect and appreciate when perusing a courtesan's works. Xue Susu's poem can also be read as a literary antecedent to the poetry by the semi-legendary Yangzhou courtesan Xiaoqing 小青 (I595-I6I2), whose name puns on qing 情 (emotions) and may therefore be rendered as "Miss Emotion". ${ }^{76}$ Historians are not agreed whether she was a historical personage or merely a figment of the literati's imagination, 77 but Xiaoqing became the epitome of the late Ming cult of emotions.

In contrast to Xiaoqing's story as imagined by the literati, Xue Susu's poetic persona does not die of her lovesickness. Xue Susu's poem instead inscribes the courtesan's voice into the literati discourse on emotions, creating resonance between her and the literati's works and establishing a literary dialogue of two equal voices. Perhaps the literati-authored discourse on Xiaoqing and her tragic fate can be read as a response to Xue Susu's advocating an equal dialogue, showing that literary men were at a loss how to deal with this other than resorting to the traditional view that women's literary talent was fraught with dangers. The formation process of the new beauty ideal - combining beauty, talent and virtue - clashed with traditional concepts and created tensions.

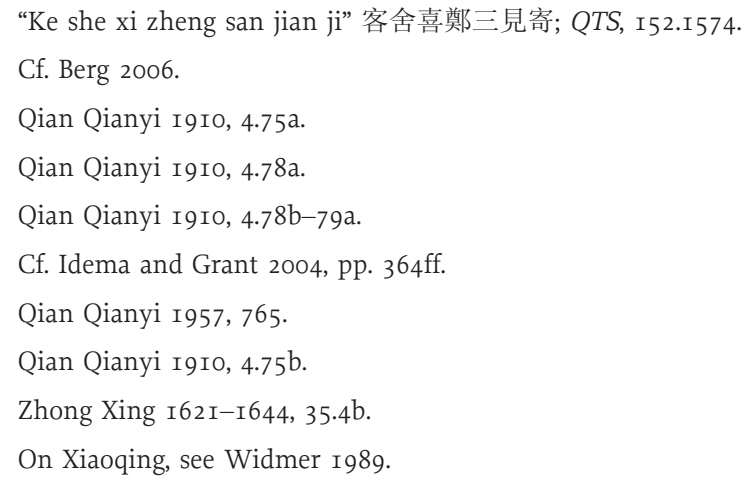




\section{The Hermit}

In her lyrical imagination the courtesan's persona does not always appear as a companion or lovesick maiden but also as a hermit. Other verses by Xue Susu transmit the woman poet's voice from outside the pleasure quarters, relegating courtesan life into the distance while celebrating the artist's solitude and independence of body and spirit instead. Consider this poem composed sometime before I6I6:

\section{Painting Orchids}

In a lonely valley there is a fine lady of unrivalled beauty, Her sash green gauze, her flesh pure jade.

It's a pity she gets mixed up with a growth of weeds, There she remains the sole admirer of her secret scent. ${ }^{78}$

\section{畫蘭}

空谷佳人絕世姿,

翠羅為帶玉為肌。

獨憐錯雜蕭蕭草, 一叚幽香秪自奇。

The inclusion of the poem in several anthologies published between I6I6 and I644 suggests its popularity with the late Ming readership. ${ }^{79}$ The opening line of this heptasyllabic quatrain evokes the image of the "jia ren" 佳人, “fine lady" of unrivalled beauty that originates in Han 漢 dynasty Emperor Wu's 武帝 (r. I4I-87 BC) court musician Li Yannian's 李延年 (c. I4O-c. 87 BC) song about the unrivalled femme fatale who topples cities and empires. ${ }^{80} \mathrm{Du}$ Fu's 杜甫 (712-770) old-style poem “Jia ren” 佳人 (“A Fine Lady”) famously features a gentlewoman fallen on hard times living in a lonely valley. The lonely valley alludes to the hiding place of the brilliant white colt (bai ju 白駒) in the Shi jing. ${ }^{81}$ According to Tang dynasty commentator Kong Yingda 孔颖达 (574-648), the wise man (xian ren 賢人) who becomes a hermit lives in obscurity in such a valley, with the implied hope of waiting for an enlightened ruler's recognition. ${ }^{82}$

In Chu ci 楚辞 (Songs of $\mathrm{Chu}$ ) the term “jia ren" denotes the morally good person, gentleman (jun zi 君子) or wise man (xian ren 賢人). ${ }^{8}$ Han Emperor Wu's poem "Qiu feng ci” 秋風辭 (“Autumn Wind Song”) links the image of an unforgettable fine lady with the elegance of orchids and fragrance of chrysanthemums. ${ }^{84}$ These flowers epitomize literati culture and feature dominantly in Xue Susu's and other courtesans' paintings.

\footnotetext{
78 Zhang Mengzheng I6I6, I.248. Zhi 秪 is rendered as 祇 in Zhong Xing I62I-44, 3I.I3a.

79 Zhang Mengzheng I6I6, 248; Zheng Wenang I620, I2a-b; Zhao Shijie I620, 6.30b; Zhong Xing I62 I-I644, 3I.I3a.

80 Ban Gu I962, 97A.395I.

8I “Jiao jiao bai ju, zai bi kong gu” 皎晈白駒、在彼空谷, Mao shi zheng yi, I IA.I I6b.

82 Mao shi zheng yi, I 1 A.r 6 b.

83 Qu Yuan 200I, I45.

84 Yue fu shi ji I998, 84.894.
} 
Like many courtesans, Xue Susu excelled at depicting orchids. Her style of painting orchids resembles that of the most famous orchid painter among courtesans Ma Xianglan, whose style name means "Orchids of the River Xiang". ${ }^{85}$ The poem can be read as mixing allusions to persons of different gender and social backgrounds: the title evokes a scholar painter or a courtesan orchid painter like Xue Susu or Ma Xianglan. The allusions to Li Yannian and Du Fu implicitly sketch Xue Susu's fine lady as both a femme fatale and a gentlewoman. In contrast to Du Fu's blue-sleeved gentlewoman, Xue Susu's protagonist wears green, a colour associated with courtesans. ${ }^{86}$ The green gauze echoes Xu Hun's 許渾 (788-c. 867) verse about a nocturnal banquet with precious musical string instruments, jade cups and elegant entertainments. ${ }^{87} \mathrm{Hu}$ Yinglin described Xue Susu's elegance (jia 佳) as unrivalled, making this courtesan a late Ming model of a "fine lady" (jia ren). ${ }^{88}$

Tang poet Li Bai described the solitary orchid growing in a secret garden, waiting for her scent to be discovered. ${ }^{89}$ This flower symbolized purity and seclusion and was perceived as a secluded, hidden rarity, just like the courtesan herself. Literatus Mao Xiang 冒襄 (I6I II693) depicted the Qinhuai courtesan Dong Xiaowan 董小宛 (I624-I65I) as “a fragrant orchid flower growing in a secluded valley".90 The orchid was also associated with a young girl's chamber or a marital chamber, symbolizing love and beauty. A union of golden orchids denoted the bond of friendship or love. The Yi jing 易經 (The Book of Changes) associates the orchid with harmony in a relationship: "The words of two people who share the same mind set have the scent of orchids."9I

Late Ming literati associated the fragrance of orchids with the Qinhuai pleasure quarters. As Yu Huai observed:

Women begin to indulge in wine from the early hours of the morning onwards, and splash about in orchid-scented baths. The scent of their clothes fills the rooms. Come noon, the fragrance of orchids, jasmine, aromatic white-flowered garoo wood and tree wax wafts about for several miles. ${ }^{92}$

The literati also imagined the orchid as a symbol of scholarly ideals. In all its different connotations, the orchid epitomizes the courtesan's mixture of feminine eroticism with masculine erudition.

Xue Susu's poetic fascination with nature and seclusion draws on Tang dynasty poetic models. Wei Yingwu's 韋應物 (737-792) nature poetry describes the scholar hermit’s gaze:

85 Cf. Weidner I988, p. 78 .

86 Cf. Mann I997, pp. I29-30.

87 “Shao zhou Shao yang lou ye yan” 韶州韶阳楼夜宴; QTS, 534.6100.

$88 \mathrm{Hu}$ Yinglin $\mathrm{1646,}$. 5 a.

89 QTS, I6r.I676.

90 Mao Xiang I992; trans. Mao Pijiang I93 , p. I2. On Mao Xiang, see ECCP, pp. 566-67; on Dong Xiaowan (zi: Bai 白), see Yu Huai I697, B.9-10; Weidner I988, pp. 98-99.

9I Zhou yi zheng yi, 7.67c.

$92 \mathrm{Yu}$ Huai 1697 , A.I. 
he "feels particular pity for the secluded grasses on the riverbank". ${ }^{93}$ Paula Varsano notes that "solitude keenly felt" informs Wei Yingwu's poetics, concluding that his poetry communicates an invisible landscape of the inner eye. ${ }^{94}$ Xue Susu borrows the Tang poet's vision of solitude but the fascination of her poetic voice with nature extends to all senses, feeling the woman's body and smelling her fragrance. Recluse, woman, grasses and orchids merge into one picture, conjuring up the landscape of the gentleman scholar's mind, the emblems of literati tradition, and the courtesan orchid painters on the Qinhuai riverbank. This picture fills the landscape of the implied courtesan poet's inner eye, communicating her solitude, abandonment, regret with her lot and hope for recognition. Late Ming anthologist Zhong Xing's comment appended to Xue Susu's poem proposes a similar reading: "She resorts to such phrases in comparison with her own circumstances. This emotion truly deserves our compassion."95

\section{CODA: THE COURTESAN POET'S LYRICAL MASKS AND THE IMPLIED READERSHIP}

The trope of the solitary or reclusive entertainer - a paradox, yet part of Xue Susu's lyrical masks - recurs throughout her literary oeuvre. A sequence of two poems by Xue Susu entitled "Du zhuo er shou” 獨酌二首 ("Drinking in Solitude”, composed before I6I6) depicts a solitary poet visited only by gulls, a metaphor for both the hermit and a person of a pure and innocent mind. $9^{6}$ The imagery alludes to Du Fu's verse "Ke zhi” 客至 (“The Guest”) yet Xue Susu's poem appears to invert Du Fu's evocation of the arrival of a visitor, emphasizing instead the contentment found in the hermit lifestyle and in painting as a solitary act. These allusions ultimately expose the lyrical mask of the solitary courtesan as a stylistic device of literary teasing: the arrival of the guest, as Du Fu's poem suggests, is never far away, and literati emblems pervade the courtesan's rhetoric, revealing her consciousness of her readership. In I633 Xue Susu inscribed a poem celebrating the joy of reclusion on a painted fan depicting chrysanthemums and bamboo, flowers that along with orchids all symbolize literati culture. ${ }^{97}$ The rhetoric of solitude places the courtesan firmly within literati tradition while showing her in tune with the current fashions of her reading audience.

The courtesan's toying with the idea of withdrawal from the world echoes the late Ming literati's frustration with official life and their desire to leave the world of politics. Many leading scholars - among them Wang Zhideng and scholar artist Chen Jiru 陳繼儒 (I558-I639) - favoured life in reclusion as hermits (shan ren 山人), or at least they liked seeing themselves portrayed as such. ${ }^{98}$ Reclusion in the mountains or the countryside often represented an attitude in the literati's minds, if not a lived experience. Besotted 
with the utopia of the scholar hermit, the literati still found it hard to resist urban temptations. 99 The courtesan's arts provided them with the illusion of reclusion within the heart of the city.

Fan Jue 范玨, another seventeenth-century courtesan painter from the Qinhuai, took the idea of reclusion to the extreme - or so at least connoisseur Yu Huai perceived it, looking back on her fate after the fall of the Ming:

She discarded all her clothes and ornaments, musical instruments, and all other items that looked gay, luxurious or extravagant. The only thing she did was to shut her doors, burn incense, make tea and sit down with nothing but a stove for brewing medicines and several volumes of sutras. ${ }^{\text {Ioo }}$

Modern Japanese scholar Ōki Yasushi 大木康 has pointed out that the literati constructed their depictions of courtesans as mirror images of their own political dreams and fantasies, in particular those related to Ming loyalism after the dynastic fall. ${ }^{\text {Ior }}$ When the Qinhuai burnt down after the cataclysm and the Qing dynasty banned prostitution, Ming loyalists depicted the vanished courtesan culture as a symbol of Ming culture. Here I argue that the courtesan's lyrical masks show her fashioning herself as a reflection of her readers' dreams. Xue Susu's poems about reclusion - written during the late Ming era of perceived crisis and decadence - present literati fantasies as the implied courtesan author's own.

Xue Susu, like many other women of her time, became a Buddhist and her poetry on religious topics foreshadows or reflects this interest. Her poems on seclusion however do not foreground the religious experience. They invoke instead courtesan culture and the pursuit of the literati arts. Her poetic persona may appear to pursue her art in solitude, but the act of writing makes it public. By publishing her works the courtesan advertises her craft, enhancing her perceived desirability and underscoring her intellectual proximity with her reading audience.

The implied readership of Xue Susu's poems would have included her clients, lovers and patrons, the literati she identified as her declared target audience by dedicating or addressing her poems to them. Publishing counted among a courtesan's ways of establishing her career and reputation. ${ }^{\text {I02 }}$ But Xue Susu's poems reach out beyond this circle: to the men who in turn dedicated their poems to her, collected her paintings and wrote prefaces or colophons for her works; the gentlewomen who wrote poems about her and other courtesans; the leading women artists who formed her circle of friends; the anthologists who immortalized her in their collections; and the publishers who produced and marketed such works for a new urban readership. ${ }^{\text {I03 }}$ The following sections look at Xue Susu's portrayals through the literati's eyes.

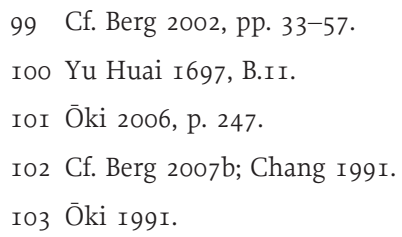




\section{THROUGH THE LITERATI'S EYES}

Here I focus on three dominant aspects in the male-authored discourse on Xue Susu: the courtesan as a seductress, scholar-collator and knight-errant. In highlighting these aspects, the literati praised her beauty, talent and virtue, a combination that poses a paradox in courtesans.

\section{The Seductress}

The scholar and bibliophile Hu Yinglin a member of the literary archaist "Latter Seven Masters” (Hou qi zi 後七子), expressed his admiration for Xue Susu as a young courtesan. ${ }^{\text {I04 }}$ $\mathrm{Hu}$ Yinglin described her perceived beauty and elegance in a work written in Beijing in I594-I595: "Xue Wu [Susu] has a seductive and elegant appearance. Her speech and her comportment are lovely." ${ }^{\circ}$

Xue Susu's biographer Qian Qianyi - possibly jointly with his wife, the ex-courtesan Liu Rushi - measured Xue Susu's beauty as transcending cultural boundaries and culturespecific yard-sticks: even "southern barbarians" - non-Han tribes at the margins of empire who saw her portrait admired her appearance, "a rare thing to happen". ${ }^{\text {oo6 }}$

$\mathrm{Hu}$ Yinglin composed a poem for Xue Susu that situates her in the Qinhuai pleasure quarters, proving that she was associated with the place in the literati's minds:

\section{Poem Written on Behalf of [Wang Tonggui] Xingfu as a Present for}

Scholar Xue [Susu] from the Western Brothel (Xiqu)

Who brought this famous flower to the Imperial garden?

How stunning that she declined the offer of a thousand taels of gold for a single smile! ${ }^{\text {I07 }}$

This Peach Leaf of the river-heaven soars across upon the breeze;

This reed in the water-country makes poetry as she embraces the moon.

This scarlet phoenix is poised to rise, for the sake of her life's partner;

Her pencilled eyebrows bear a faint frown, on account of her true love.

Bo [Juyi]'s "Song of Everlasting Sorrow" is extremely relevant to be recited;

She has already dusted off the bridegroom's bed, to attend upon his jade-trimmed zither. ${ }^{\text {I08 }}$

為行父贈西曲薛生

誰垭名花到上林, 居然一笑謝千金。

江天桃葉凌風渡,

\footnotetext{
I04 Hu Yinglin I736-1796, 59.3a.

I05 Hu Yinglin I646, 5a.

I06 Qian Qianyi I957, p. 770.

I07 The story goes that she declined wealthy suitors who offered one thousand taels in gold; see Qian Qianyi I957, p. 770.

I08 Hu Yinglin I736-1796, 59.3a.
} 


\begin{abstract}
水國萧臀抱月吟。
朱鳳半趐緣比翼,

翠蛾微斂為同心。

白家長恨殊堪誦,

早拂東床侍玉琴。
\end{abstract}

These regulated verses describe an expensive courtesan expecting a visit from her lover. Xue Susu chose Wang Tonggui 王同軌 (c. I530-after I608) as her poetry teacher when she was fourteen. ${ }^{\text {I09 }}$ Wang Tonggui, the author of a bestselling anecdotal collection, took his friend $\mathrm{Hu}$ Yinglin to the pleasure quarters and introduced him to Xue Susu. ${ }^{\text {I }}{ }^{\text {I }}$ The poem implies that Xue Susu lived during her time in Nanjing at Peach Leaf Ford (Taoye du 桃葉度) near the Bridge of Convenient Fording, a tourist attraction in the Qinhuai. The place would remind visitors of the Jin 晉 dynasty (265-4I9) calligrapher and scholar Wang Xianzhi 王獻之 (344-386) who wrote a poem about the place where he parted from his lover and concubine, the courtesan Taoye 桃葉, or Peach Leaf, who then crossed the canal at this point.

In this poem the story of Wang Xianzhi's courtesan lover Peach Leaf presents an early adumbration of the Wang surname. The second couplet in the poem implies a comparison of Peach Leaf and Xue Susu, describing the courtesan yearning for her loved one. The closing line of the poem refers to the bridegroom's bed, in particular alluding to the story from the Jin shu 晉書 of the original bridegroom, poet and calligrapher Wang Xizhi 王羲之 (c. 32I-379), the second adumbration of the Wang surname. The poem ends on this note, implicitly celebrating the union of the implied lover Wang Tonggui with Xue Susu. Allusions to Bo Juyi's "Song of Everlasting Sorrow" - an early adumbration occurs in line five, followed by a direct reference in line seven - model their relationship on the ultimate Chinese romance.

The comparison of the courtesan to China's most celebrated femme fatale Yang Guifei

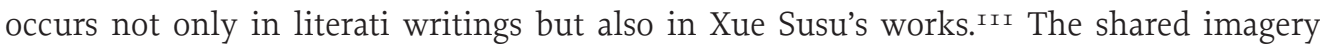
however involves conflicting negotiations in the male and the female poetic voices. While Xue Susu's poem on the feast with Censor He invites the reader to participate in a rendezvous with her client, Hu Yinglin's poem leads the reader into the bedroom. Xue Susu's poem highlights the courtesan's intellectual and emotional matching of her guest, celebrating a companionate relationship and a union of equals. Hu Yinglin's poem by contrast depicts the courtesan as a precious commodity, emphasizing Xue Susu's allure while revelling in his friend's conquest. The different gender perspectives reveal opposite agendas. This portrayal of the courtesan in the dominant male-authored discourse may go some way in explaining why the courtesan poet - despite her social and cultural negotiations - remained at the margin of elite culture.

Io9 Zi: Xingfu 王行甫, 王行父. Hu Yinglin I736-I796, 60.2b. Hu Yinglin I646, 5a. On Wang Tonggui, see $D M B$, pp. I $442-44$.

I Io Hu Yinglin I736-I796, 59.3b.

I I Xue Susu I644-I9I I, pp. 658-59. 


\section{The Scholar-Collator}

$\mathrm{Hu}$ Yinglin recalled that on their first meeting, Xue Susu had called him the "most outstanding scholar of his time". ${ }^{12}$ He in turn addressed her with the honorific "Scholar Xue” (Xue sheng 薛生) and enthused: "Even those famous painters with outstanding skills cannot surpass her." II3 By using this gendered honorific, a form of address usually reserved for a male scholar, $\mathrm{Hu}$ Yinglin here masculinizes the courtesan, according her honorary male status.

Courtesans reached male-level proficiency in the arts, in particular calligraphy and painting, as well as poetry. Hu Yinglin praised Xue Susu's calligraphy:

She excels at regular style calligraphy and surpasses everybody in painting bamboo and orchids. She employs swift strokes of the brush and her paintings testify to her liveliness. ${ }^{\text {II } 4}$

$\mathrm{Hu}$ Yinglin used the semi-honorific title of female "collator" or "book reviser" (jiao shu 校書) to refer to Xue Susu during her time in the Qinhuai. ${ }^{I 5}$ The literati had been using this title for courtesans of outstanding literary talent since the Tang dynasty courtesan poet Xue Tao 薛濤 (768-c. 832). It referred to famous courtesans who formed intellectual companionships with elite men and shared their interest in learning, helping out in the scholar's studio composing, collating, editing, proofreading and annotating literary works. Wang Zhideng used the title for Ma Xianglan. ${ }^{\text {II } 6}$ The courtesan Li Yin addressed Liu Rushi as such in her poems. ${ }^{I I 7}$ The title confirmed a courtesan's perceived high ranking and cultural prestige. Xue Susu used the term “female collator" (nü jiao shu 女校書) as her sobriquet in her signature seal on a painting of chrysanthemums and bamboo dated I633. ${ }^{\text {II } 8}$ This shows that Xue Susu still placed herself in the courtesan's artistic tradition even as a woman married into the elite. In another poem Hu Yinglin combines references to Xue Susu as "Scholar Xue" with her sobriquet Qiaoqiao 巧巧, explaining that she was born on the Double Seventh, the festival of the cowherd and weaver maid. ${ }^{\text {II }}$ Here he identifies her as a reincarnation of the legendary celestial lover. In his perception the courtesan's eroticism thrives on her androgynous nature.

\section{The Knight-errant}

The literati revealed their fascination with Xue Susu's androgynous nature and martial spirit in their praise of her archery and equestrian skills. Her martial arts inspired artistic

\footnotetext{
I 2 Hu Yinglin I736-I796, 59.4a.

I $3 \mathrm{Hu}$ Yinglin I646, 5 a.

I $4 \mathrm{Hu}$ Yinglin I646, 5 a.

I 5 Hu Yinglin I646, 5a; Hu Yinglin I736-I796, 59.3b; Zhu Yizun I705.98.5a.

I 6 LFZ, p. I53.

II7 Li Yin I643, I.IIa.

I 8 Cf. Weidner et al. I988, p. 85.

I $9 \mathrm{Hu}$ Yinglin I736-I796, 59.3b.
} 
and literary representations in the late Ming era and beyond, as a woodblock carving of Xue Susu on horseback practising archery shows. ${ }^{\mathrm{I} 20}$ In her childhood she practised archery on horseback outside the city walls on the open fields. Later she performed in public attracting large crowds of spectators. ${ }^{\mathrm{II}}$ Poets including $\mathrm{Hu}$ Yinglin and Lu Bi 陸怩 from Yangzhou 揚 州 made her equestrian performances the subject of their verses and depicted how she entertained guests at parties with her archery. ${ }^{\text {I22 }}$ The literati celebrated her androgyny and admired her martial games, portraying her as crossing gender boundaries.

Xue Susu was not the only courtesan celebrated for her androgyny in literati discourse: Liu Rushi cross-dressed as a male scholar when she went for her first meeting with Qian Qianyi; literati writings describe how late Ming courtesan poet Yu Sulan went out riding her horse in the moonlight with a servant girl in attendance. ${ }^{\text {I23 }}$ In his recent survey of women and literature in the Ming and Qing era, modern Japanese scholar Gōyama Kiwamu 合山究 points out that the courtesan's very allure and appeal to the literati derived from her perceived masculinity and androgyny. ${ }^{\mathrm{I24}}$ This made her a ready trope for literati self-identification.

Literati discourse casts Xue Susu as a female knight-errant (nü xia 女俠), ${ }^{125}$ coupling her martial spirit with a strong sense of morality, virtue and justice. According to classical storyteller Song Maocheng 宋梑澄 (I569-c. I620) from Songjiang, in I592 Xue Susu urged her lover during her time in Beijing, National University student Yuan Baode 袁 保德 (d. I604), to suppress a rebellion. She later encouraged him to lead an expedition against the Japanese in Korea and offered to provide the necessary funding. When he failed to comply Xue Susu left in a huff and ended the relationship. ${ }^{\text {I26 }}$ This episode portrays her as a political activist on the national stage with a Confucian mission to save the empire. ${ }^{\text {I27 }}$

$\mathrm{Hu}$ Yinglin confirmed that Xue Susu's spirit was "heroic" and called her a knighterrant. ${ }^{\text {I28 }}$ He noted that she regarded herself as bold, generous, and chivalrous. ${ }^{\text {I29 }}$ One collector of Xue Susu's paintings, Secretary in the Ministry of War Fan Yunlin 笵允臨

\footnotetext{
I20 Wu Youru I983, vol. I.

I2I Qian Qianyi I957, p. 770.

I $22 \mathrm{Hu}$ Yinglin I646, 5a; Hu Yinglin I736-I796, 59.3b-4a. For Lu Bi’s poem, see Zhu Yizun I705, 98.5a/b; Qian Qianyi 1957, 770. For another poem for Xue Susu by Lu Bi (zi Wucong 無從), see Lu Bi I644-I9I I, 27.6b.

I23 Qian Qianyi I957, p. 773; Xu Naichang I909, 7.3b.

I24 Gōyama 2006, pp. 549-55.

I 25 For details, see Barr I997, p. I22.

I 26 Song Maocheng I573-I620, 5.27b-28b.

I 27 Song Maocheng was a frequent visitor to the pleasure quarters and immortalized a number of courtesans in his poems; he was also a friend of Yuan Baode's who joined his circle in Beijing and came into contact with Xue Susu; cf. Barr I997, pp. I20-2 I. In I6I2 Song Maocheng first published his classical tale "Fu qing nong zhuan” 負情儂傳 (“The Faithless Lover”) about the courtesan Du Shiniang 杜十娘. Her story became most famous in the colloquial version “Du Shiniang nu chen bai bao xiang” 杜十娘怒沉百寶箱 (“Du Shiniang Sinks the Jewel Box in Anger”) published in I624 in Feng Menglong's second San yan anthology. The literati portrayed Du Shiniang as showing loyalty, courage and determination similar to Xue Susu and connected her story with the cult of emotions. Xue Susu probably inspired some elements in Du Shiniang's story.
}

I $28 \mathrm{Hu}$ Yinglin I646, 5 a.

I29 Hu Yinglin I646, 5 a. 
(I558-I64I) also praised Xue Susu as a female knight-errant in his colophon to her "Mo hua tu juan” 墨花圖卷 (“Ink Flower Scroll”) dated I6I5:

Sujun's other feats of shooting birds with pellets and generously parting with one thousand pieces of gold to save somebody from poverty truly make her a female knight-errant for all time. ${ }^{\text {130 }}$

Female knights-errant first featured as a literary theme in Tang dynasty tales. ${ }^{\text {I3 }}$ The term originally refers to a young woman who receives training in the martial arts to avenge a wrong done to her parents, kill a powerful enemy and fulfil her filial duty. She has androgynous traits and heroic powers. In the Ming era the concept of nü xia broadened into metaphorical usage but the Qing era reversed this trend again. ${ }^{\text {I32 }}$ The metaphorical depiction of the courtesan as a knight-errant therefore pinpoints a late Ming phenomenon. Allan Barr has described the concept of chivalry (xia 俠) as a "powerful force guiding human behaviour", of even greater importance than emotions. ${ }^{133}$ The concern with chivalry reflects the literati's attempts to restore a martial spirit to late Ming culture.

Other courtesans portrayed as knights-errant include Liu Rushi, Ma Xianglan and

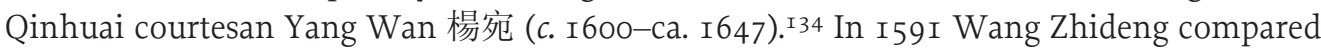
Ma Xianglan's generosity and trustworthiness to two male Han dynasty knights-errant. ${ }^{135}$ Another Qinhuai beauty Kou Baimen 寇白門 ( $f$ l. mid-seventeenth century) acquired the status of knight-errant in the literati's perception when she paid one thousand pieces of gold to buy herself out of an unsatisfactory marriage to a wealthy military commander. In Yu Huai's words, she subsequently "reverted to life as a female knight-errant", lived her life as she pleased, received poets and statesmen at her garden studio and later ended a union with a scholar when she lost interest in him. ${ }^{\text {I36 }}$ Independence of body and spirit characterized her perceived chivalry, although at Yu Huai's time of writing after the fall of the Ming dynasty his loyalism and nostalgia may have added further layers of meaning.

The phenomenon of endowing women, and in particular courtesans, with chivalry resonates through late Ming discourse: the anthology Qing shi lei lüe 情史類略 (Anatomy of Love), compiled after I628 by Feng Menglong 馮夢龍 (I574-I646), also features a story about a courtesan knight-errant from the Qinhuai pleasure quarters called "Zhang Xiaosan” 張小三. ${ }^{137}$

The late Ming courtesans' voices echo the male discourse that endows them with a martial and chivalrous spirit. The Suzhou courtesan Du Wei 杜韋 (d. I577) called herself

\footnotetext{
I30 Painting in The Asian Art Museum of San Francisco, The Avery Brundage Collection (66D22).

I3I Cf. Altenburger 2000.

I32 Cf. Li I997, pp. 60-63.

I33 Cf. Barr I997, p. I Iо.

I34 On Yang Wan, see Qian Qianyi I957, pp. 773-74; WWTC, pp. 333-36.

I35 LFZ, pp. I52-53.

I36 Yu Huai r697, B.I5-I6.

I37 Feng Menglong I984, I.26-27.
} 
a "knight among women". ${ }^{138}$ Another poem by Xue Susu about a feast with Censor He confirms women's potential as knights-errant: "We both agree that women can show chivalry" 共說繡衣能任俠. ${ }^{\mathrm{I}} 9$ Xue Susu chose “Fifth Boy" (Wulang 五郎) as a sobriquet, ${ }^{\mathrm{I}}{ }^{\circ}$ and described herself as a female knight-errant (nü xia). ${ }^{\text {I4I }}$

Both the literati and the courtesans, then, perceived the figure of the female knighterrant as characterized by generosity, disregard for money, compassion, a martial spirit, military interests, androgynous behaviour, determination, erotic allure, independence, autonomy of spirit, and an unconventional moral and social outlook. By portraying courtesans as knights-errant the literati endowed them with a paradoxical mix of attributes that no other woman was likely to have: in the literati's imagination courtesans mirrored their own dreams and desires and transcended the social boundaries imposed by gender and class.

Another paradox in late Ming discourse on courtesans lies in the conflation of the concepts of chivalry and chastity. Chastity was not what would be expected in a courtesan. Yu Huai teased the Qinhuai courtesan Tenth Lady Li when she changed her name to Zhenmei 貞美 (Chaste Beauty): "You certainly have beauty, but you do lack chastity!" She replied with tears in her eyes: "If I am not chaste, that's my fate, there's nothing I can do about it!” 142

Feng Menglong placed the story about the Qinhuai courtesan knight-errant Zhang Xiaosan in the section “Qing zhen lei” 情貞類 (“On chastity”) of his Qing shi. Zhang Xiaosan swears loyalty to a merchant and becomes his concubine. The merchant lavishes his entire fortune on her, plunging his family into ruin. When she hears no more from him, Zhang Xiaosan visits his family, realizes that she has caused his family's downfall, and returns everything she received from him. She nurses the dying merchant and offers to serve his principal wife. Forced by her parents to return to the Qinhuai, she vows chastity until death. This story combines courtesan culture with the cults of emotions and widow chastity.

Feng Menglong's appended commentary stresses that - contrary to received opinion emotions and chastity exist among courtesans. Ōki Yasushi has shown that Feng Menglong's San yan 三言 stories also show sympathy with courtesans, depicting them as good citizens with a capacity for emotions. ${ }^{43}$ Feng Menglong fell in love with the Suzhou courtesan Hou Huiqing 侯慧卿. When she married a rich merchant, he aired his feelings in lyric verses (san qu 散曲) entitled “Yuan li ci” 怨離詞 (“Song about Hating to Say good-bye") dedicated to Hou Huiqing. " ${ }^{\text {I4 }}$

Late Ming arbiter of taste Chen Jiru defined chivalry (xia) as loyalty, chastity and reliability:

\footnotetext{
I38 Barr I997, p. I27.

I39 Zhang Mengzheng I6I6, I.80.

I40 Tang Shuyu I928-I936, 5.5b.

I4I Zhu Qiqian I928-I936, I7b.

I42 Yu Huai I697, B.6.

I43 Ōki 2003, p. 233.

I44 Cf. Ōki I989, pp. 8I-83.
} 
A chivalrous official is a man who is loyal, A chivalrous lady is a woman who is chaste,

And a chivalrous companion is someone who is reliable. ${ }^{\mathrm{I} 45}$

This shows that in late Ming perceptions the chivalrous courtesan takes on an androgynous role: she embodies a masculine version of chastity on an allegorical level, as a mirror image of the loyal official and reliable companion.

\section{IN THE GENTLEWOMAN'S GAZE}

The multiple discourses about Xue Susu show the courtesan not only through male eyes but also from the female perspective, depicted through the gentlewoman's gaze. Late Ming gentlewomen had some contact with high-class courtesans and even composed poems for courtesans.

Fan Yunlin's wife, the unconventional gentlewoman Xu Yuan 徐媛 (I560-I620) from Suzhou, shared his admiration for Xue Susu and wrote a series of five poems highlighting the courtesan's artistic and athletic talents, her beauty, chivalry, martial spirit and intelligence. ${ }^{\mathrm{I} 6} \mathrm{Xu}$ Yuan compares Xue Susu to the Tang courtesan Xue Tao and to a military leader called Xue:

Your steps are so delicate that lotus grows beneath the curves of your soles, Your waist so willowy and feather-light you could dance on a palm.

A flower goddess, you show chivalry and moral integrity...

Holding a fine horse you discuss the battle strategy,

The plans in your mind are as good as those of ten thousand Commander Xues. ${ }^{\mathrm{I} 47}$
雙彎嬌䘽步蓮生,
一束蠻腰舞掌輕
花神俠骨氣縱橫, ...
手把龍文談虎客,
胸羅十萬薛嵩兵。

$\mathrm{Xu}$ Yuan may have overstepped social boundaries in forging friendships with courtesans but it did not diminish her literary fame. ${ }^{148}$

Lu Qingzi 陸卿子 ( $f$ l. I590), another gentlewoman poet from Suzhou who shared Xu Yuan's literary circle, also composed verses for courtesans: ${ }^{\text {I49 }}$

\footnotetext{
I45 Chen Jiru I628-44, 4.37a. On Chen, see ECCP, pp. 83-84; Barr 1997, p. I Io.

I46 On Xu Yuan, see WWTC, pp. 257-65; Ko I994, p. I70.

I47 Xu Yuan I6I3, 8.23a-23b; possibly referring to Tang dynasty general Xue Rengui 萳仁靔 (6I4-683), a famous archer.

I48 On Xu Yuan's friendship with courtesans and Lu Qingzi, see Ko 1994, pp. 266-74.

I49 On Lu Qingzi, see WWTC, pp. 239-57.
} 


\section{To a Courtesan}

In a frock the hue of halcyon and a gown purple as peony, You arrive deep in a meadow dotted with flowers on your ornamental carriage. Picking a red leaf to inscribe some impromptu verse, You have no need to envy Collator Xue of bygone days. ${ }^{150}$

贈妓

$$
\begin{aligned}
& \text { 翡翠為裙苟藥裾, } \\
& \text { 百花深處駐雲車。 } \\
& \text { 自將紅葉閒題字, } \\
& \text { 不羡當時薛較書。 }
\end{aligned}
$$

The poem evokes shades of green and red, colours associated with courtesans. ${ }^{\text {I5I }}$ It is not clear whether Lu Qingzi ever knew or met Xue Susu. Her reference to Xue Tao may be read as an allusion to Xue Susu, as in Xu Yuan's poem. Hence it is possible that Lu Qingzi's poem addresses no other than Xue Susu.

Lu Qingzi celebrates in her poetry the emotions she professes to share with female friends, both gentlewomen and courtesans. This poem assumes the connoisseur's or client's voice expressing admiration for the courtesan's physical beauty and literary talent. Dorothy Ko has described such homo-social relationships as a "friendship-love continuum", ${ }^{152}$ but it is also conceivable that in singing the courtesans' praises the gentlewoman poets simply echo literati discourse on the new ideal of womanhood combining beauty, talent and virtue. ${ }^{53}$ Helen Dunstan has debunked the myth of late imperial literati wives condoning their husbands' philandering or expressing homo-erotic desire for their husbands' lovers. ${ }^{\mathrm{I}} 54$ Perhaps gentlewomen with literary ambitions implicitly compared themselves with the recognized achievements of leading courtesan poets. The gentlewoman's act of valorizing courtesans moreover imitated literati convention. This form of literary mimesis provided one way for a writing gentlewoman to begin to inscribe her voice into elite culture.

Huang Yuanjie, a professional artist and writer from an impoverished literati family in Jiaxing, exchanged calligraphy and paintings with Xue Susu. ${ }^{155}$ As a widow Huang Yuanjie supported herself by selling her paintings and poetry and stayed with gentlewomen poets and also Liu Rushi. During the final years of the Ming dynasty Xue Susu became Huang Yuanjie's neighbour and friend in Hangzhou. ${ }^{156}$ This shows how courtesans and gentlewomen occasionally shared the same literary culture and social circle.

Qian Qianyi's biography mainly focuses on Xue Susu's physical beauty and athletic skills. Current scholarship still debates the extent of Liu Rushi's editorial or authorial

\footnotetext{
I50 Zhong Xing I62I-I644, 32.20b.

I5 I Cf. Mann I997, pp. I29-30.

I52 Ko I994, p. 266.

I53 Cf. Ko I994, pp. I43-76.

I54 Dunstan 2007.

I55 On Huang Yuanjie, see WWTC, pp. 357-63.

I56 Yun Zhu I83I-I836, fulu, I6b.
} 
involvement in this work. ${ }^{157}$ If Liu Rushi indeed authored the biographies appended to the women poets' section of Qian Qianyi's anthology, as Kang-i Sun Chang claims, ${ }^{158}$ then this text may offer a rare portrayal of Xue Susu by another courtesan. It immortalizes Xue Susu's physical attributes as well as her intellectual achievements.

The tropes of the woman scholar and the solitary poet in the discourse on Xue Susu foreshadow forms of self-fashioning among early Qing writing gentlewomen, as poems by Banana Garden poetry club (Jiao yuan shi she 焦園詩社) members in late seventeenthcentury Hangzhou show. ${ }^{159}$ In the early nineteenth century the gentlewoman poet Gui Maoyi 歸禁儀 (c. I762-c. I832) from Changshu, associated with Yuan Mei’s 袁枚 (I7I6I798) female students, composed a poem in memory of Xue Susu, testifying to the courtesan's legacy and impact across the centuries. ${ }^{.60}$

\section{CONCLUDING REMARKS}

The analysis of the discourse on Xue Susu sheds light on how and why the courtesan seduced late imperial Chinese minds. This study retraces the network of social negotiations and exchanges in Xue Susu's world by reconstructing her representations from a jigsaw of literary portraits by herself, the literati and women writers. These texts show from different perspectives how both men and women did not only trade poems but also bodies, emotions, dreams and aspirations. In this respect these sources also rewrite the boundaries of elegance, femininity and gentility.

In sum, three dominant aspects emerge in analysing Xue Susu's lyrical masks: the courtesan as a companion to her literati guests, a lovesick maiden and a hermit, each of which, respectively, advocates social and intellectual equality with her clients, echoes the generic conventions of courtesan poetry and reflects literati fashions and fantasies. Xue Susu's poetic persona also transcends the traditional and physical boundaries of gender and class, fusing the male and female poetic voices into one while inscribing the trope of the courtesan into the very heart of genteel culture. It is conceivable that the courtesan's fashioning of the talented woman as the scholar's companion contributed to the concept formation of the companionate marriage as a new ideal for ruling-class couples in the Ming/Qing era. Analysis of her discourse enables us to retrace and witness the formation of a new ideal of partnership and marriage in early modern China.

The literati by contrast portray Xue Susu as a seductress, scholar-collator, and knighterrant, combining beauty, talent and virtue. Dorothy Ko has described how this combination became the new beauty ideal for gentlewomen during the seventeenth century. ${ }^{\mathrm{I} I}$ Xue Susu appears as one of the first women to personify this ideal. Perhaps the discourse on Xue Susu played a formative role in its conception, providing rare insights into the social negotiations and discursive processes of a new beauty ideal in the making. This

\footnotetext{
I57 Berg 2007b, p. 279.

I58 Chang I997, pp. I53-56.

I59 See Berg 2007c.

I60 Gui Maoyi I832, 3.32a.

I6I Cf. Ko I994, pp. I43-76.
} 
study shows how such an ideal emerged from late sixteenth-century courtesan culture and shaped the gentlewoman's world in the seventeenth century.

Xue Susu appears to have treasured the illusion of her autonomy while striving to strengthen her social standing. Her literary and artistic talents certainly helped her enhance her reputation among the elite. Fame could negotiate social and financial benefits. Unlike other courtesans who remained independent throughout their lives, Xue Susu attempted to change her lot by means of marriage. Perhaps she merely succeeded where others - such as Ma Xianglan - did not. When Xue Susu's partnerships failed to satisfy her or fulfil her aspirations, she would try again. She preserved the dream of her autonomy of body and spirit in her art and lyrical imagination. The construction of her image helped her negotiate her trajectory through life: it responded to late Ming literati desires while presenting a stylized poetic persona for public consumption.

While Xue Susu's poems declare feelings of love and loyalty for her clients, the men highlight her erotic allure and social value as a priced commodity. These discrepancies in the discourses of Xue Susu and the men around her go some way in explaining her failed marital histories. Perhaps she never found a soul mate able to provide companionship to her as a married woman or appreciate her intelligence outside the framework of courtesan culture.

The gentlewomen's perceptions of Xue Susu and courtesan culture show how elite women began to assimilate into literati culture, making dominant themes, tropes and topoi from literati discourse their own. Their participation in the discourse on Xue Susu reveals the courtesan's impact on writing women in early modern China and the gradual rise of the writing gentlewoman in elite culture from the late Ming onwards.

\section{REFERENCES}

Altenburger 2000

Altenburger, Roland. The Sword or the Needle: The Female Knight-Errant (Xia) in Traditional Chinese Fiction. Habilitationsschrift, Philosophische Fakultät der Universität Zürich, 2000.

Ban Gu I962

Ban Gu. Han Shu. Beijing: Zhonghua shuju, I962.

Barr I997

Barr, Allan. "The Wanli Context of the 'Courtesan's Jewel Box' Story.” Harvard Journal of Asiatic Studies 57:I (I997), pp. I07-4I.

Berg 2002

Berg, Daria. Carnival in China: A Reading of the Xingshi yinyuan zhuan. Leiden: E. J. Brill, 2002.

Berg 2003

Berg, Daria. "What the Messenger of Souls Has to Say: New Historicism and the Poetics of Chinese Culture." In Reading East Asian Writing: The Limits of Literary Theory, ed. Michel Hockx and Ivo Smits. London: RoutledgeCurzon, 2003, pp. I7 I-203.

Berg 2004

Berg, Daria. "Der Kult um die Unsterbliche Tanyangzi: Biographie als Bestseller im China der späten Kaiserzeit." In Schreiben über Frauen in China: Ihre Literarisierung im historischen Schriftum und ihr gesellschaftlicher Status in der Geschichte, ed. Jianfei Kralle and Dennis Schilling. Wiesbaden: Harrassowitz, 2004, pp. 285-3Io.

Berg 2006

Berg, Daria. "Miss Emotion: Women, Books and Culture in Seventeenth-Century Jiangnan.” In Love, Hatred and Other Passions: Questions and Themes on Emotions in Chinese Civilization, ed. Paolo Santangelo and Donatella Guida. Leiden: E. J. Brill, 2006, pp. 3I4-30. 
Berg $2007 a$

Berg, Daria. “Amazon, Artist, and Adventurer: A Courtesan in Late Imperial China.” In The Human Tradition in Modern China, ed. Ken J. Hammond and Kristin Stapleton. Lanham, MD: Rowman \& Littlefield, 2007, pp. I5-32. Berg $2007 \mathrm{~b}$

Berg, Daria. "Female Self-Fashioning in Late Imperial China: How the Gentlewoman and the Courtesan Edited Her Story and Rewrote Hi/story." In Reading China: Fiction, History and the Dynamics of Discourse. Essays in Honour of Professor Glen Dudbridge, ed. Daria Berg. Leiden: E. J. Brill, 2007, pp. 238-89.

Berg 2007C

Berg, Daria. "Negotiating Gentility: The Banana Garden Poetry Club in Seventeenth-Century Jiangnan." In The Quest for Gentility in China: Negotiations beyond Gender and Class, ed. Daria Berg and Chloë Starr. London: Routledge, 2007, pp. 73-93.

Berg and Starr 2007

Berg Daria, and Chloë Starr, eds. The Quest for Gentility in China: Negotiations beyond Gender and Class. London: Routledge, 2007.

Cass I999

Cass, Victoria Baldwin. Dangerous Women: Warriors, Grannies, and Geishas of the Ming. Lanham, MD: Rowman and Littlefield, I999.

Chang I99I

Chang, Kang-i Sun. The Late Ming Poet Ch'en Tzu-lung: Crises of Love and Loyalism. New Haven: Yale University Press, I99I.

Chang I997

Chang, Kang-i Sun. "Ming and Qing Anthologies of Women’s Poetry and Their Selection Strategies." In Writing Women in Late Imperial China, ed. Ellen Widmer and Kang-i Sun Chang. Stanford, CA: Stanford University Press, I997, pp. I47-70.

Chang and Saussy I999

Chang Kang-i Sun and Haun Saussy, eds. Women Writers of Traditional China: An Anthology of Poetry and Criticism. Stanford, CA: Stanford University Press, I999.

Chen Jiru I628-I644

Chen Jiru. Chen Meigong xiansheng quanji. Huating: n.p., I628-I644.

Chen Shan 2007

Chen Shan. "Yi cai ru hua: nüxing shijiao zhong de Xue Susu jiqi huazuo". Nanjing yishu xueyuan xuebao 4 (2007), pp. 89-93.

Chen Yinke 1980

Chen Yinke. Liu Rushi bie zhuan. 3 vols. Shanghai: Shanghai guji chubanshe, I980.

Dudbridge I995

Dudbridge, Glen. Religious Experience and Lay Society in T'ang China: A Reading of Tai Fu's Kuang-i chi. Cambridge: Cambridge University Press, I 995.

Dudbridge 2000

Dudbridge, Glen. Lost Books of Medieval China. London: The British Library, 2000.

Dunstan 2007

Dunstan, Helen. "If Chen Yun Had Written about Her 'Lesbianism': Rereading the Memoirs of a Bereaved Philanderer.” Asia Major, Third Series 20:2 (2007), pp. I03-22.

Feng I984

Feng, Menglong. Qing shi lei lüe. Changsha: Yuelu shushe, I984.

Goodrich and Fang I976

Goodrich Carrington L. and Chao-ying Fang, eds. Dictionary of Ming Biography I368-1644. New York: Columbia University Press, I976.

Gōyama 2006 Gōyama, Kiwamu. Min Shin jidai no josei to bungaku. Tokyo: Kyuko shoin, 2006.

Greenblatt I988

Greenblatt, Stephen. Shakespearean Negotiations: The Circulation of Social Energy in Renaissance England. Oxford: Clarendon Press, I988.

Gu shi shi jiu shou ji shi 1955

Gu shi shi jiu shou ji shi. Ed. Sui Shusen. Beijing: Zhonghua shuju, I955.

Gugong bowuguan 2007

Gugong bowuguan. "Xue Susu.” http://www.dpm.org.cn/china/e/eg/o6-or.htm, accessed 26 June 2007. 
Gui I 832

Gui, Maoyi. Хiи yи хи сao. Shanghai: Li shi, I832.

He 2004

He, Junhong. "Ming Qing jiancangjia dui nühuajia yishu de jianshang.” Gugong bowuyuan yuankan I I I:I (2004), pp. 28-39.

Hu Wenkai 1985

Hu Wenkai. Lidai funü zhuzuokao. Rev. ed. Shanghai: Shanghai guji chubanshe, I985.

$\mathrm{Hu}$ Yinglin s986a

Hu Yinglin. Jia yi sheng yan. Repr. in Shuoku, ed. Wang Wenru. Wan wei shan tang, I646. Repr. Hangzhou: Zhejiang guji chubanshe, I986.

$\mathrm{Hu}$ Yinglin I986b

Hu Yinglin. Shao shi shan fang ji. Wen yuan ge, I736-1796. Repr. Taibei: Taiwan shangwu yin shuguan, I986.

Hummel I943-I944

Hummel Arthur, ed. Eminent Chinese of the Ch’ing Period, I644-I9I 2. Washington: Government Printing Office, I943-I944.

Idema and Grant 2004

Idema, Wilt and Beata, Grant. The Red Brush: Writing Women of Imperial China. Cambridge, MA: Harvard University Asia Center, 2004.

Ji 1997

Ji, Xian. Gui xiu ji. I644-I9ı I ed. Repr. Jinan: Qilu shushe, I997.

Ko I994

Ko, Dorothy. Teachers of the Inner Chambers: Women and Culture in Seventeenth-Century China. Stanford, CA: Stanford University Press, I994.

Le Roy Ladurie I980

Le Roy Ladurie, Emmanuel. Montaillou: Cathars and Catholics in a French Village I294-I324, trans. Barbara Bray. London: Penguin Books, I980.

Li Rihua 1682

Li Rihua. "Xue Su hua li Guanyin xiang." In Shigutang shuhua huikao, ed. Bian Yongyu. Wuxing: Jiangshi Mijunlou, I682.

Li Yin 1643

Li Yin. Zhu xiao xuan yin cao. N.p.: I643.

Li Yingzheng 2002

Li Yingzheng. "Xue Su lin zhao cheng zhi chui xiao mei ren tu ge.” In Ming shi ji shi, comp. Chen Tian. Guiyang: Tingshizhai, I644-I9I I. Repr. Shanghai: Shanghai guji chubanshe, 2002.

Li, Wai-yee I997

Li, Wai-yee. "The Late Ming Courtesan: Invention of a Cultural Ideal.” In Writing Women in Late Imperial China, ed. Ellen Widmer and Kang-i Sun Chang. Stanford, CA: Stanford University Press, I997, pp. 46-73.

Liu 2007

Liu, Suping. "Wan Ming mingji yishu de shehui wenhua jiedu." Wenshi bolan Io (2007), pp. $25-27$.

Lu Bi 1957

Lu Bi. “Guan Susu xie tan ge.” In Lie chao shi ji xiao zhuan, Qian Qianyi. Shanghai: Gudian wenxue chubanshe, I957.

Lu Bi I644-I9II

Lu Bi. "Zeng Wu ji Xue Susu.” In Geng jian, Ming shi ji shi, comp. Chen Tian. Guiyang: Tingshizhai, I644-I9I I.

Lu Qingzi I62I-I644

Lu Qingzi. “Zeng ji.” In Ming yuan shi gui, Zhong Xing. N.p., I62 I-I644.

Lu Qinli I983

Lu Qinli, comp. Xian Qin Han Wei Nanbeichao shi. Beijing: Zhonghua shuju, I983.

Mann I997

Mann, Susan. Precious Records: Women in China's Long Eighteenth Century, Stanford, CA: Stanford University Press, I997.

Mao Pijiang I93I

Mao Pijiang. The Reminiscences of Tung Hsiao-wan, trans. Pan Tze-yen. Shanghai: Commercial Press, I93I.

Mao shi zheng yi 1983

Mao shi zheng yi. Song ed. Repr. by Ruan Yuan, in Shi san jing zhu shu, I8r6. Repr. Beijing: Zhonghua shuju chuban, I983. 
Mao Xiang 1982

Mao Xiang. Ying mei an yi yu. In Meihua wenxue mingzhu congkan, ed. Zhu Jianmang. Shanghai: Shanghai shudian, I982.

Mao Yuanyi 1964 Mao Yuanyi, "Xi xuan qing niao ji”. In Shuofu xu. Vol. 43. Tao Ting ed. I646. Repr. Taibei: Xinxing shuju, I964. Miura 1992

Miura, Shūichi. "Shinkō Yu Anki bon seiritsu no jidaiteki jōkyō - Banreki no chishikijin to dōkyō." In Chūgoku kodōkyōshi kenkyū, ed. Yoshikawa Tadao. Kyoto: Dōhōsha, I992, pp. 5I I-64.

Nienhauser 1986

Nienhauser William H. Jr., ed. and comp. The Indiana Companion to Traditional Chinese Literature. Bloomington, IN: Indiana University Press, 1986.

Ōki 1989

Ōki, Yasushi. "Fū Muryū to gijo." Hiroshima daigaku bungakubu kiyō 48 (I989), pp. 7 I-9I.

Ōki 1990

Ōki, Yasushi. "Sanjin Chin Keiju to sono shuppan katsudō." In Yamane Yukio kyoju taikyu kinen Mindai shi ronshu. Tokyo: Kyuko shoin, I99o.

Ōki I99I

Ōki, Yasushi. "Minmatsu Kōnan ni okeru shuppan bunka no kenkyū." Hiroshima daigaku bungakubu kiyō 50:I (I99I), pp. 74-IO2.

Ōki $2002 a$

Ōki, Yasushi. Chūgoku yūri kūkan: Min Shin shinwai gijo no sekai. Tokyo: Aonisha, $2002 a$.

Ōki 2002 b

Ōki, Yasushi. "Shindai joryū shijin to Ryū Joshi - Chōkaidō bijutsukan sō 'Ko Bi ga Ryū Joshi sho gōheki satsu' ni yosete”. Chōkaidō bijutsukan kenkyū kiyō 3 (2002b), pp. 7-18.

Ōki 2003

Ōki, Yasushi. Fū Bōryū "Sanka" no kenkyū. Tokyo: Keisō shobō, 2003.

Ōki 2006

Ōki, Yasushi. "Mao Xiang and Yu Huai." In Trauma and Transcendence in Early Qing Literature, ed. Wilt L. Idema, Wai-yee Li and Ellen Widmer. Cambridge, MA: Harvard University Asia Center, 2006, pp. 23I-48.

Qian I957

Qian, Qianyi. Lie chao shi ji xiao zhuan. Shanghai: Gudian wenxue chubanshe, I957.

Qian I9I0

Qian, Qianyi. Lie chao shi ji. Shanghai: Guoguang shuju, I9ıо.

$\mathrm{Qu} 200 \mathrm{I}$

Qu, Yuan. Shijing, Chuci. Ed. Kong Yi. Shanghai: Shanghai cishu chubanshe, 200I.

Quan Tang shi 1985

Quan Tang shi. Beijing: Zhong hua shu ju, repr. 1985.

Shen 1980

Shen, Defu. Wan li ye huo bian. Beijing: Zhonghua shuju, I980.

Shi 1999

Shi, Yude. Ming yuan ya ge. Zhengzhou: Zhongzhou guji chubanshe, I999.

Song 2002

Song, Maocheng. Jiu yue ji. N.p.: 1573-1620. Repr. Shanghai: Shanghai guji chubanshe, 2002.

$\mathrm{Su} 200 \mathrm{I}$

Su, Shi. Su Shi shiji hezhu. Ed. and annot. Feng Yingliu. Shanghai: Shanghai guji chubanshe, 200I.

Tang I928-I936

Tang, Shuyu. Yu tai hua shi. Shanghai: Shenzhou guoguangshe, I928-1936.

Tseng 1955

Tseng, Yu-ho. "Hsüeh Wu and Her Orchids in the Collection of the Honolulu Academy of Arts." Arts Asiatiques 2:3 (I955), pp. 197-208.

Varsano 1994

Varsano, Paula. "The Invisible Landscape of Wei Yingwu (737-792)." Harvard Journal of Asiatic Studies 54:2 (1994), pp. 407-35.

Waltner 1987

Waltner, Ann. "T'an-yang-tzu and Wang Shih-chen: Visionary and Bureaucrat in the Late Ming". Late Imperial China 8:I (1987), pp. I05-33. 
Wang Duanshu I667

Wang Duanshu. Ming yuan shi wei. N.p.: Qing yin tang, I667.

Wang Tonggui 2002

Wang Tonggui. Er tan lei zeng. I603. Xuxiu siku quanshu, vol. I268. Shanghai: Shanghai guji chubanshe, 2002.

Weidner et al. I988

Weidner, Marsha et al. Views from Jade Terrace: Chinese Women Artists, I300-19I 2. Indianapolis and Rizzoli, NY: Museum of Art, I988.

Wetzel 2002

Wetzel, Jean. "Hidden Connections: Courtesans in the Art World of the Ming Dynasty.” Women's Studies 31:5 (2002), pp. 645-69.

Widmer I989

Widmer, Ellen. "The Epistolary World of Female Talent in Seventeenth-Century China." Late Imperial China I0:2 (I989), pp. I-43.

Widmer and Chang I997

Widmer Ellen and Kang-i Sun Chang, eds. Writing Women in Late Imperial China. Stanford, CA: Stanford University Press, I997.

$\mathrm{Wu}$ I983

Wu, Youru. Wu Youru huabao. Vol. I. Shanghai: Shanghai guji chubanshe, I983.

Xu Naichang I909

Xu Naichang. Gui xiu ci chao. N.p.: Xiao tan luan shi, I909.

$\mathrm{Xu}$ and Qian I69o

$\mathrm{Xu}$, Shumin and Qian, Yue, comps. Zhong xiang ci. Kangxi ed. N.p., c. I69o.

$\mathrm{Xu}$ Yuan I6r3

Xu Yuan. Luo wei yin. Suzhou: Fan ed., I6r3.

Xue 1998

Xue, Susu, Hua suo shi. In Shui bian lin xia, ed. Hunan manshi, I644-I9r I. Repr. Beijing: Shumu wenxian chubanshe, I998.

Yu 1697

Yu, Huai. Ban qiao za ji. I697. Ed. Shanghai: Shanghai zheng qi shu ju, I949.

Yue fu shi ji 1998

Yue fu shi ji. Ed. Guo Maoqian. Shanghai: Shanghai guji chubanshe, I998.

Yun I83I-I836

Yun, Zhu. Guo chao gui xiu zheng shi ji. Beijing: Hong xiang guan, I83 I-I836.

Zeitlin 2006

Zeitlin, Judith T. "Notes of Flesh' and the Courtesan's Song in Seventeenth-Century China.” In The Courtesan's Arts: Cross-Cultural Perspectives, ed. Martha Feldman and Bonnie Gordon. Oxford: Oxford University Press, 2006, pp. 75-99.

Zhang I994

Zhang, Mengzheng. Qing lou yun yu. I6r6. Repr. Shanghai: Shanghai guji chubanshe, I994.

Zhao I620

Zhao, Shijie. Ming yuan hui shi. N.p.: Zhang Zhengyue, I620.

Zhong I997

Zhong, Xing. Ming yuan shi gui. I62 I-I644. Repr. Jinan: Qilu shushe chuban, I997.

Zhou I973

Zhou, Ruchang. "'Hongloumeng' ji Cao Xueqin youguan wenwu xulu yisu.” Wenwu 2 (I973), pp. 20-3I.

Zhou yi zheng yi I816

Zhou yi zheng yi. Song ed. Repr. by RuanYuan in Shi san jing zhu shu, I8I6. Repr. Beijing: Zhonghua shuju chuban, I983.

Zhu Qiqian I928-1936

Zhu Qiqian. Nü gong zhuan zheng lüe. Repr. Shanghai: Shenzhou guoguangshe, I928-I936.

Zhu Yizun I962

Zhu Yizun. Ming shi zong. Kangxi ed, preface I705. Repr. Taibei: Shijie shuju, I962. 